\title{
Dimensions Services Quality of Indonesian Islamic Banking (Case Study Customer SantrisBank Muamalat Indonesia)
}

\author{
Abadi Sanosra \\ University of Muhammadiyah Jember
}

\begin{abstract}
:
Purpose: The purpose of this study was to explore the customer perception of santris about the meaning of quality Islamic banking services and to create a model Islamic bank service quality .

Design / Methodology/Approach: The research method used was qualitative research methods with techniques of data collection methods Indeft Interview. Informants as research subjects santris are customers who have savings in Bank Muamalat Indonesia (BMI) regional of Eks- Karesidenan Besuki 5 ( Five ) informants.

Results: The study found the santris have the view that the customers of Islamic banks is the bank run by sharia istem and quality service Islamic bank must contain elements of sharia. This study found that service quality model consists of 8 (Eight) dimension as a means of measuring the quality of Islamic banking services.

Originality/value : research is one of the few studies evaluating the students community in the context of Islamic banking in Indonesia.
\end{abstract}

Keywords: Meaning Services Quality, Customer santris, Islamic Banking .

\section{Introduction}

Characteristics of Indonesian culture is influenced by the principles of Islamic laws and values of the Islamic religion. One social group that is very influential in the cultural system and political system in Indonesia is the santris or the community of santris, namely a group or community of Islam that is very closely adhere to the teachings of Islam is pure, Geertz (1984) . In addition to its pattern of life is influenced teachings of Islam generally santris a people who have studied Islam at a boarding school or formal education institutions Islam breath .

The existence of the santis or the community of santris has influenced the emergence of an institution that is an economic muamalah banking system known as Islamic banking. The development of Islamic bank in Indonesia was relatively late when compared with Muslim countries as well as with non-Muslim majority countries though. In view of the number of Islamic banks at the national level the number of Islamic banks has increased by 12 Islamic banks ( BUS ). However, when viewed from the side of the market share of Islamic banking stagnation or slowdown in growth for over 3 years from 2012 to 2015 only able to reach the national banking market share as much as $4.9 \%$ ( statistical report FSA 2015). Perumbuhan slowdown is causing pessimism among observers of Islamic banking will be the future of the Islamic banking in Indonesia .

Islamic banks or Islamic banking is called bank that adopts sharia or apply the principles of sharia (Islamic), meaning that Islamic banking has the distinguishing feature in comparison with the conventional banks. Another differentiator of Islamic banking in addition to providing the advantages of earthly hereafter also able to provide benefits for customers in other words, saving money while doing a good deed. In addition to khususan Islamic banking market share came from devout Muslims or who reject the concept of usury. Although Islamic banks aimed at Muslims does not mean acceptance of Muslims against Islamic banking is high enough, the fact is the market share of Islamic banking in the national banking market is very low at only $4.9 \%$. This condition is of course begs the question why the development of Islamic banking decelerating. To answer this question researchers are trying to assume that the quality of Islamic banking is still low so it has not been able to compete with conventional banking. Based on the above research background can finally collated the following research questions:

1. What is the meaning of customer service quality as perceived by santris Eks Karesidenan Besuki, East Java

2. How Quality dimensional model of Islamic Banking Services in accordance with customer perception of santris Eks Karesidenan Besuki East Java.

3. Based on the background of the research problem, the purpose to be achieved in this study are :

4. Uncover and understand the meaning of quality of service according to the public perception of santri Throughout Eks Karesidenan Besuki East Java .

5. Formulating dimensional model of Islamic Banking Service Quality in accordance with customer perception of santris Eks Karesidenan Besuki East Java . 


\section{Services quality}

Service quality can be defined as how much the difference between reality with the expectations of the customers on the services they receive,( Parasuraman , 1984). Grönroos (1979) defines service quality as a result of the perception of The comparison between customer expectations with actual performance of service . How do customers rate the service received will determine the service quality. There are two ways to assess services (gronrooos, 1979 , namely :

a. Technicaloutcome : where assessment is conducted when the results of the waiter has taken place or the work of the service delivery itself.

b. Process : where the assessment is carried out when the process or the quality of the delivery of such services .

Zeithaml, Berry and Parasuraman (1996 ) developed a scale SERVQUAL ( services quality) that include questions about consumers 'expectations of service quality and consumer perception of the service quality they receive , by defining the quality of service as the difference between expectations and consumers' perceptions of service quality .Furthermore, Cronin and Taylor (1992) proposed an alternative measure known as SERVPERF ( services performance) that includes questions about the quality of service performance. In this study remained on five dimensions mentioned above but in the measurement scale used is the scale SERVPERF ( services performance) developed by Cronin and Taylor. The reason for choosing this measurement because it is measured is the perception or assessment of the quality customer service that the receipt, while if SERVQUAL ( services quality) measured is the gap between expectation and performance .

\section{Islamic Services Quality}

The few studies that have produced the quality dimensions of service that aims to measure the quality of service of Islam and is used in the company that does business with the Islamic legal system such as Islamic banking. Othman and owen (2002) is a pioneer who built the Islamic dimension of service quality , by modifying the model SERVQUAL and find a model CARTER consisting of 6 (six) dimensions are compliance / adherence, assurance, reliability, tangibles, empathy and responsiveness . Jabnoun and khalifa (2005) The purpose of the research is to develop pengkuran quality of service in the United Arab Emirates ( UAE ) and simultaneously test the conventional banking and Islamic banking in the United Arab Emirates.The study found 7 (seven) dimensions of quality of service of Islam consists of physical evidence, assurance, responsiveness, reliability and empathy ditambahan two new dimensions called values (values) and image (image).

Rahim (2010) conducted a study in the UK under the title: Service Quality of Inglish Banks. one of the goals of this research is to develop a service quality measurement scale British Islamic bank in accordance with the British Muslim community perspective. The study found the model English Islamic Banking Service Quality (EIBSQ), which consists of 5 (five) dimensions, Responsiveness, Credibility, Islamic Tangibles, Accessibility, and Image Bank. . Gayatri \& Chew (2013) construct a separate building or a special new dimension to establish quality of service measurement Islam. The object of research is in services such as hotels, restaurants, airlines, and retail. The research found six (6) dimensions of quality of service measurement of Islam comprising: Values of Islam, Halal / Haram, Attention to Religious Activity, Honesty, Humility, Humanity and Faith.

\section{Research Methodology}

This study aims to gain greater understanding of the perceptions of individuals who have an active role in the process of making certain decisions. More precisely how a customer thinks construction backgrounds of students decide or choose to use the services of banks to apply Islamic principles that Islamic banking within the meaning of ( noemena ) quality of service that they perceive . based on these objectives, the type of appropriate research used in this research is qualitative research. Qualitative research is a method to explore and understand the meaning by individuals or group of people coming from social or humanitarian issues (Cresswell , 2013 ) . The location of research in the area of ex- Besuki residency consisting of the district, Jember, Bondowoso , Situbondo and Banyuwangi. This area was chosen because, according to researchers for Eks Karesidenan Besukiis still part of horse hooves Region which is a regional community-based santri in East Java, where the influence of the education agency Pasantren very strong in community life .The informant is the source of data for indeep interviews ( Idepth interview ) in this study is a community students who become customers of Bank Muamalat Indonesia, which operates in the area of ex- Besuki residency, as many as five people consisting of clerics and students. Determination of informants were mainly determined because they are willing to fill the letter the willingness to participate and be willing to do an interview recorded 2 times, ie 90 minutes and 60 minutes, and the selection of informants done in deliberate or purposive .

\section{Technique Data Analysis}

Qualitative data analysis is required in determining the dimensions of service quality as well as items of each dimension of service quality. To determine the dimensions and items of service quality research using 
data collection methods with in-depth interviews (indeept interview) and to facilitate discussions in order to focus the discussion the researchers first provide a list of items that already exist in previous studies. Procedure indeept interview starting with an introductory session and explanation of the purpose of the interview. The whole informant was given the freedom to express their opinion on an issue discussed.

\section{Results and Discussion}

Based on the results of in indeft interview with the informant as much as 5 (five) informant is generally found that customers make sense that the Islamic bank is a bank that in practice the financial system were implemented based on the financial system in accordance with the teachings of Islam that does not include the element of riba, While aspects of the quality of banking services in general customer view that is essentially between conventional banking and Islamic banking is not much different from what it means applied conventional banking in providing services similar to what is applied in Islamic banking. But despite having a similarity in the forms of service but should highlight the Islamic banking to Islamannya (shar, i) in the elements of a particular service.

Results of in-depth interviews (indeft interview) with the informant as much as 5 (five) informant is generally found that customers make sense that the Islamic bank is a bank that in practice the financial system were implemented based on the financial system in accordance with the teachings of Islam that does not include the element of riba, While aspects of the quality of banking services in general customer view that is essentially between conventional banking Islamic banking is not much different from what applied means conventional bank in providing services similar to what is applied in Islamic banking. But despite having a similarity in the forms of service but should highlight the Islamic banking to Islamic (shar, i) in the elements of a particular service.

The elements of the service that is fundamental in the sense that these elements are an absolute necessity that there should be minsalnya place of worship, how to dress employees, includes symbols of Islam as a function propaganda and of course there are many other elements. The existence of the service charge be Islamic in the show which is in the form of tangible or intangible. Intangible services are forms of physical services are seen by customers minsalnya places of worship, how to dress employees, the symbols of Islam. While the intangibles such as employee attitude, speed role in providing services, and so forth.

These dimensions is the most important attribute in the system or there must be a service of Bank Muamalat Indonesia (BMI) specifically or Islamic banking in general. This means that the Islamic banking or Bank Muamalat Indonesia (BMI) should be able to provide services in accordance with customer expectations are based prinsisp principles of Islamic law in the Islamic banking use as a reference or guidance in running the financial system and system services. In each dimension contains elements of Islamic, Islamic size is contained in every dimension of the faithful present in the item or indicator measurement. despite having a similarity in naming dimension but in each of these dimensions containing measures in accordance with aspects of sharia.Here is the definition of the dimensions of quality of services and items or indicators of each service quality in accordance with customer perception of students who become customers of Islamic banks through analysis indeft interview as follows:

1. Dimensions compliance is the assessment of students islamic bank customers to the bank's ability to run the system Operational and financial service system in accordance with the principles of law or the ability of banks to provide product services in accordance with the provisions contained in the sources of Islamic law as in Al-Qur'an, hadith, Ij'ma and Qiyas.

2. Dimensions Tangible is customer ratings of students of the ability of Islamic banks to provide facilities services seen by customers in the operational process services to clients, supporting facilities are in addition to displays of equipment and adequate modren also accommodate the needs of worship and availability Gents and woman.

3. Dimensions Reliability is an assessment of customers' employees and students of the ability of Islamic banks in giving or providing services to customers according to their needs. The ability of employees to perform tasks and the ability to answer any questions the customers on the basis of fiqh of loyal product.

4. Dimension Responsiveness is a customer assessment of students against employees in completing its tasks, the bank's ability to be responsive in dealing with problems that arise and response to problems being experienced customers. This attitude also shows a form of responsibility that earnest without feeling forced.

5. Dimension ansurance is customer ratings the students the sense of security that is provided to customers both Islamic Bank security in the transaction, transaction security and security devices use confidential customer and security in the halal financial products, both in terms of financial management and in-process service.

6. Dimensions Empathy is a public Islamic banking customer ratings of students of the attitudes and behavior of customer sevices, his ability to communicate with customers, understand the needs of customers and 
easy to contact. Islamic aspect that should be in the highlight inside is the attitude of sincere empathy with no make-up or as an obligation per se, but because ynag sincere intentions.

7. dimensional consistency) is a public Islamic banking customer ratings of students against the bank's ability to execute the agreement (clause) in any contract until the transaction ends. If the dimensions of compliance (adherence) is a measure of a product's compliance service Islamic bank with the sources of Islamic law, dimensional consistency is the ability.

8. Dimension Transparency is the assessment of customers' willingness of students to Islamic banks to be open in all transaction processing and the willingness of banks to discuss together and provide an opportunity to its customers about the content of the agreement in any contract signed before the product.

\section{Conclusion}

1. Customers santris understand Islamic bank in accordance in accordance with their understanding, that Islamic banks are banks that are under in accordance with Islamic law or the principles of Islam, both in terms of its financial system and role in aspects of the service that is given.

2. There are 8 (eight) dimension in quality model layana sharia banking industry, especially in Islamic banking, which consists of obedience, responsiveness, consistency, Transparent, Physical Evidence, Reliability, Assurance, and Empathy. This model is called the model of Islamic banking service quality.

\section{References}

[1]. Creswell.W.John and Clark Vicki L, Plano 2007. Mixed methods research. Sage publications.

[2]. Cronin, J.J dan Taylor, S.A., 1992, “Measuring Service Quality: A Reexamination and Extension”, Journal of Marketing,July (56):55- 68.-------1994,"SERVPERF Versus SERVQUAL:Reconciling Performance Based and Perception Minus Expections Measurement of Service Quality", Journal of Marketing, January (58): 125-131.

[3]. Dick,A.S dan Basu, K., 1994,"Customer Loyalty : Toward an Integrated Conceptual Framewor k", Journal of The Academy Marketing Science, Vol.22, p.99- 113.

[4]. Dimyati, Muhamad, 2009, Analisa SEM Dalam Uji pengaruh Beberapa VariabelTerhadap Loyalitas, kajian Berbasis Riset Pada Debitur Kredit Usaha Kecil. Edisi pertama - Jakarta: Mitra Wicana Media.

[5]. Easterby - Smith, M., Thorpe, R. And Lowe, A. (1991) 'Management Research : An Introduction', Sage Publications

[6]. Evelyn Ehrlich dan Duke Faneli, 2004, The financial Services marketing, : Bloomberg press, prencenton.

[7]. Fandy Tjiptono, 2005, Prinsip-Prisip Total Quality Service (TQS) :Andi Offset.

[8]. Gronroos, Christian, 1990. Service Management and Marketing, Lexington. MA : Lexington Books.

[9]. Gronross, Christian, 1982, A Service Quality Model and it s Marketing Implications, European Journal of Marketing.

[10]. Miles and Huberman, 1994, Qualitative Data analysis, second edition, sage Publications : London

[11]. Jabnoun Naceur and Khalifa Azaddin,.2005, “A customized measureof service Quality in the UAE” Managing Service Quality Vol.15 No.4, 2005 pp.374-388q Emerald Group Publishing Limited 0960-4529

[12]. Kasmir, 2007, Manajemen Perbankan :PT RajaGrafindo Persada.

[13]. Lovelock, Christopher, 2002. Service Marketing and management, second Edition, new York : Prentice Hall.

[14]. Othman, AbdulQawi and Owen, Lynn.,2001. “Adopting And Measuring Customer Service Quality (Sq) ; In islamic banks: a case study in Kuwait finance house”, International Journal of Islamic Financial Services Vol. 3. No. 1.

[15]. Othman, Abdu 1Qawi and Owen, Lynn.,2002. "The multi dimensionality of carter model to measure Customer service quality (sq) in islamic banking industry:A study in kuwait finance house, International Journal of Islamic Financial Services Vol. 3. No. 4.

[16]. Parasuraman, A., Zeithaml, V.A dan Berry, L.L., 1994, "Reassessment of Expectations as a Comparison Standart in Measuring Service Quality : Implication for Further Research", Journal of Marketing, January,111:124.----1988, "SERVQUAL: A Multiple-Item Scale for Measuring Consumer Perceptions of Service Quality”, Journal of Retailing, Vol.4(1).-------,1885,“A Conceptual Model of Service Quality and It's Implications for Future Research", Journal of Marketing,Vol.4,p.41

[17]. Parasuraman, A., Zeithaml, V. A and Malhotra, A. (2005), “E-S-QUAL : a multiple - item scale for assessing electronic service quality", Journal of Service Research, Vol .7 No. 3, pp. 213 - 33.

[18]. Pedersen, Per E, Nysveen, Herbjon. 2004. Shopbot banking : and Experimental Studi of Cuctomer satisfaction and loyality..

[19]. Saunders, M. Lewis, P. and Thornhill, A., 2003. Research Methods for Business Students, 3rd ed. London. Prentice Hall.

[20]. Sugiono, 2002, Metode Penelitian Bisnis, Bandung: CV Alfabeta.

[21]. Ziethaml, Valerie A., Leonard L. Berry, and A. Parasuraman, 1996, "The BehavioralConsequences of Service Quality", Journal ofMarketing, Volume 60, April 1996, pp. 31-46.

[22]. - -------and Bitner Jo Mary, 1996. Service Marketing, New York : Mcgraw- Hill Company.

[23]. ------2003. Service Marketing : Integrating Customer Focus Across the Firm, $3^{\text {rd }}$ Editionn. New York: Irwin McGraw-Hill. 